Jurnal Tanah dan Sumberdaya Lahan Vol 7 No 2 : 305-314, 2020

e-ISSN:2549-9793, doi: 10.21776/ub.jts1.2020.007.2.15

\title{
MONITORING HAMA DAN PENYAKIT TANAMAN DALAM PERLINDUNGAN KOLEKSI TANAMAN DI KEBUN RAYA PURWODADI
}

\section{Monitoring of Plant Pest and Disease in the Protection of Plant Collections in Purwodadi Botanical Garden}

\author{
Linda Wige Ningrum ${ }^{1 *}$, Dewi Retnosari ${ }^{2}$ \\ ${ }^{1}$ Kebun Raya Purwodadi, Pusat Penelitian Konservasi Tumbuhan dan Kebun Raya - LIPI \\ (Research Center for Plant Conservation and Botanic Garden - LIPI) \\ Jl. Raya Surabaya - Malang Km. 65, Purwodadi, Pasuruan - Jawa Timur 67163 \\ ${ }^{2}$ Fakultas Kehutanan, Institut Pertanian Malang, Malang-Jawa Timur \\ *Penulis korespondensi: lindawige18@gmail.com
}

\begin{abstract}
Purwodadi Botanical Garden is a botanical garden that specifically designated to ex situ plant conservation with typical habitats of low lands and dry areas. In an effort to protect and maintain the collection of plants, one of the things that must be carried out is the monitoring of plant pests and diseases. The research aimed to find out the plant pests and diseases that infect in plant collections at Vak I-V in Purwodadi Botanical Gardens. The method used was a descriptive observation and literature study, while the secondary data were books and environmental maps. There were nine types of pests and nine types of diseases. Pests and diseases are dominated by Leaf Spot Disease, Black Ants, Red Ants, and Lawana candida. They attack some plants, such as from family of Sapotaceae, Sterculiaceae, Mimosaceae, Moraceae, etc. The results of this study can be used as a material consideration in efforts to prevent and increase ex-situ conservation in the Purwodadi Botanical Garden.
\end{abstract}

Keywords: ex-situ conservation, monitoring, plant pests and diseases

\section{Pendahuluan}

Indonesia merupakan negara yang mempunyai sebutan megadiversity country yaitu mempunyai keanekaragaman hayati yang tinggi baik flora maupun fauna. Dalam menjaga keanekaragaman tumbuhan (flora) tersebut, adanya kebun raya di Indonesia selain menjadi salah satu pusat konservasi tumbuhan juga berperan utama dalam menyeimbangkan ekosistem suatu wilayah. Salah satu kebun raya di Indonesia adalah Kebun Raya Purwodadi (KRP) dimana terletak di dataran rendah dengan karakter wilayahnya yang kering sehingga peranan KRP selain untuk konservasi tumbuhan juga berperan utama dalam menjaga konservasi air, tanah, dan kualitas iklim mikro yang hasilnya dapat juga dirasakan oleh masyarakat sekitar kebun raya. Dalam menjalankan tugas dan fungsi KRP maka hal yang utama yang dibutuhkan salah satunya adalah melakukan perlindungan tanaman koleksi yang ada di KRP. Perlindungan tanaman mempunyai peranan yang sangat penting dan tidak dapat dipisahkan dari usaha peningkatan kualitas dan kuantitas tanaman koleksi dalam masa pertumbuhannya, dan menjaga kesehatan tanaman terutama dari serangan hama dan penyakit, serta dapat memperkecil resiko tidak berproduksinya suatu tanaman. Hal itu dikarenakan walaupun langkah-langkah lainnya dari budidaya suatu tanaman (penanaman, pemupukan, pengairan, penyiangan) sudah dilakukan dengan baik, tetapi pengendalian terhadap hama dan penyakit diabaikan, maka apa yang dilakukan pada kegiatan konservasi tanaman koleksi akan 


\section{Jurnal Tanah dan Sumberdaya Lahan Vol 7 No 2 : 305-314, 2020 e-ISSN:2549-9793, doi: 10.21776/ub.jts1.2020.007.2.15}

terancam rusak atau akan dapat mati apalagi jika hama dan penyakitnya sampai menjangkiti tanaman koleksi yang termasuk tanaman langka. Penelitian juga telah dilakukan oleh Damaiyani dan Lestari (2011) tentang inventarisasi hama dan penyakit, penelitian ini lebih memfokuskan pada hama dan penyakit pada koleksi pakupakuan di KRP. Hasil dari penelitian menunjukkan bahwa dari 67 spesies paku, sebanyak 15 spesies diantaranya terserang penyakit dan 3 spesies terserang hama.

Hama adalah semua binatang yang mengganggu dan merugikan tanaman yang diusahakan manusia. Apabila asalnya bukan dari binatang gangguan itu akan disebut penyakit, misalnya gangguan dari virus, bakteri, jamur, tumbuh-tumbuhan yang bertingkat rendah atau yang sedikit lebih tinggi, kekurangan unsurunsur makanan dan lain-lainnya (Pracaya, 1992).

Penyakit tumbuhan dapat disebabkan oleh faktor biotik dan abiotik. Penyebab penyakit yang bersifat biotik umumnya parasitik pada tumbuahan, dapat ditularkan, dan disebut penyakit biogenik. Penyakit yang bersifat abiotik tidak parasit, tidak menular, dan biasa disebut penyakit fisiogenik (Triharso, 1996). Menurut Nasution (2008), penyakit bisa muncul karena disuatu tempat ada tanaman, pathogen serta lingkungan. Hal ini yang disebut segitiga penyakit dimana munculnya penyakit karena tiga faktor itu. Salah satu faktor tidak ada atau tidak memenuhi syarat maka penyakit tidak akan muncul.

Adanya serangan hama dan penyakit, maka akan terjadi susut kuantitatif, susut kualitatif dan susut daya tumbuh (Pranata, 1982). Hama dan penyakit pada tanaman merupakan salah satu kendala yang sangat mengganggu dalam usaha konservasi tanaman koleksi. Serangannya pada tanaman dapat datang secara mendadak dan dapat bersifat eksplosif (meluas), sehingga dalam waktu yang relatif singkat seringkali dapat mematikan seluruh tanaman koleksi. Hal itu mempengaruhi kualitas lingkungan sekitar, sehingga upaya konservasi baik dalam menjaga tumbuhan dan lingkungan sekitar akan juga menurun. Tujuan penelitian ini adalah untuk mengetahui hama dan penyakit tanaman yang menjangkiti koleksi tanaman di lingkungan 1 dan 2 Kebun Raya Purwodadi (KRP) sehingga nantinya terdapat strategi upaya lanjutan dalam melindungi koleksi tanaman di KRP.

\section{Bahan dan Metode}

Penelitian dilakukan di Kebun Raya Purwodadi dengan melakukan observasi pada Vak I sampai dengan Vak V (sebanyak 24 sub-vak) yang berada di Lingkungan 1 dan 2 KRP. Pelaksanaan penelitian dilakukan selama dua bulan, yaitu sejak bulan Agustus - September 2019. Alat yang digunakan antara lain alat tulis, kamera, buku lingkungan Vak I sampai dengan Vak V, peta lingkungan Vak I sampai dengan vak $\mathrm{V}$, dan Peta KRP, Formulir D3 untuk pengisian tanaman koleksi yang terserang Hama dan Penyakit Tanaman (HPT) pada saat observasi, serta beberapa referensi mengenai hama dan penyakit tanaman. Obyek yang diamati ialah vegetasi yang terdapat pada Vak I sampai dengan Vak V (sebanyak 24 sub-vak). Penelitian ini menggunakan metode observasi diskriptif dan studi literatur. Teknik pelaksanaannya dilakukan observasi langsung dalam pengumpulan data primer, dan studi literatur dilakukan dengan cara mempelajari beberapa jurnal dan penelitian terdahulu (mengenai HPT, klasifikasi hama serangga,penyakit tanaman, dll). Terdapat dua sumber data, yaitu data primer dan data sekunder, data primer didapatkan dari hasil pengamatan di kebun mengenai HPT yang ada, serta hasil observasi lain, sedangkan data sekunder didapatkan dari peta koleksi dan buku lingkungan KRP. Data yang didapat diklasifikasikan berdasarkan buku referensi yang ada, dan disesuaikan dengan ciri-ciri HPT tersebut.

\section{Hasil dan Pembahasan}

Hasil penelitian pada Vak 1-V dengan 24 Sub Vak yang telah diobservasi disajikan dalam Tabel 1.

Berdasarkan hasil pengamatan, ditemukan sembilan jenis hama dan sembilan jenis penyakit, serta ada beberapa tanaman pengganggu (parasit) lainnya yang merusak tumbuhan koleksi seperti liana, gulma, dan benalu. Dari hasil tersebut ada pula yang belum diketahui pasti jenis HPT penyebabnya atau faktor lainnya, karena kesulitan mengidentifikasi ketika melihat kondisi beberapa tumbuhan tersebut, dan salah satu efeknya terdapat kerusakan secara mekanik yaitu akar pohon dapat terangkat / terkoyak dari tanah. 
Jurnal Tanah dan Sumberdaya Lahan Vol 7 No 2 : 305-314, 2020

e-ISSN:2549-9793, doi: 10.21776/ub.jts1.2020.007.2.15

Tabel 1. Hasil dari inventarisasi hama dan penyakit.

\begin{tabular}{|c|c|c|c|c|c|}
\hline Vak & $\begin{array}{c}\text { HPT dan jenis } \\
\text { pengganggu } \\
\text { lainnya }\end{array}$ & $\begin{array}{c}\text { Jumlah } \\
\text { Tumbuhan } \\
\text { Koleksi } \\
\text { yang } \\
\text { Terserang }\end{array}$ & Gejala & $\begin{array}{l}\text { Tingkat } \\
\text { Serangan }\end{array}$ & $\begin{array}{c}\text { Terserang } \\
\text { Bagian }\end{array}$ \\
\hline \multirow[t]{4}{*}{$\begin{array}{l}\text { I A } \\
(8)\end{array}$} & $\begin{array}{l}\text { Leaf Spot } \\
\text { Disease }\end{array}$ & 4 & Daun Kering Sebagian & $\begin{array}{l}\text { Rendah- } \\
\text { Medium }\end{array}$ & Daun \\
\hline & - & 2 & $\begin{array}{c}\text { Tidak Ada Daun, Batang } \\
\text { Keropos }\end{array}$ & Kritis & $\begin{array}{l}\text { Daun, } \\
\text { Batang }\end{array}$ \\
\hline & Wilt & 1 & Daun Layu dan Pucat & $\begin{array}{l}\text { Rendah- } \\
\text { Medium }\end{array}$ & Daun \\
\hline & Wereng Lilin & 1 & $\begin{array}{c}\text { Bubuk Putih pada Selubung } \\
\text { Pembungkus Bunga }\end{array}$ & Rendah & Bunga \\
\hline \multirow[t]{5}{*}{$\begin{array}{l}\text { I B } \\
(12)\end{array}$} & Semut Hitam & 4 & $\begin{array}{l}\text { Batang Keropos dan Tumbuh } \\
\text { Miring. Daun Kuning-Kering }\end{array}$ & $\begin{array}{l}\text { Medium- } \\
\text { Tinggi }\end{array}$ & Batang \\
\hline & - & 1 & Tidak Ada Daun. Batang Kering & Kritis & $\begin{array}{l}\text { Daun, } \\
\text { Batang }\end{array}$ \\
\hline & $\begin{array}{l}\text { Leaf Spot } \\
\text { Disease }\end{array}$ & 2 & Daun Berlubang Kering, Bercak & $\begin{array}{l}\text { Medium- } \\
\text { Tinggi }\end{array}$ & Daun \\
\hline & Kurang Kalsium & 2 & $\begin{array}{c}\text { Daun Berkerut-Kerut, Hijau } \\
\text { Normal }\end{array}$ & $\begin{array}{l}\text { Medium- } \\
\text { Tinggi }\end{array}$ & Daun \\
\hline & $\begin{array}{l}\text { Semut Hitam } \\
\text { Dan Jamur }\end{array}$ & 3 & Tercerabut, Hampir Ambruk & Tinggi & $\begin{array}{l}\text { Akar, } \\
\text { Batang }\end{array}$ \\
\hline \multirow[t]{3}{*}{$\begin{array}{l}\text { I C } \\
(5)\end{array}$} & Semut Hitam & 2 & Sarang Semut pada Akar & $\begin{array}{l}\text { Rendah- } \\
\text { Medium }\end{array}$ & $\begin{array}{l}\text { Akar, } \\
\text { Batang }\end{array}$ \\
\hline & Semut Merah & 2 & $\begin{array}{c}\text { Daun Melekat menjadi Sarang } \\
\text { Semut }\end{array}$ & Medium & $\begin{array}{l}\text { Akar, } \\
\text { Batang }\end{array}$ \\
\hline & - & 1 & $\begin{array}{l}\text { Batang Mulai Miring, Hampir } \\
\text { Ambruk }\end{array}$ & Tinggi & $\begin{array}{l}\text { Akar, } \\
\text { Batang }\end{array}$ \\
\hline \multirow[t]{8}{*}{$\begin{array}{l}\text { I D } \\
(20)\end{array}$} & Kepik Hitam & 1 & $\begin{array}{c}\text { Telur Kepik pada Tepi Daun, } \\
\text { Tunas Bagian Bawah. }\end{array}$ & Rendah & Daun \\
\hline & Semut Hitam & 9 & $\begin{array}{c}\text { Sarang Semut pada Akar dan } \\
\text { Batang. }\end{array}$ & $\begin{array}{l}\text { Medium- } \\
\text { Tinggi }\end{array}$ & $\begin{array}{l}\text { Akar, } \\
\text { Batang }\end{array}$ \\
\hline & $\begin{array}{l}\text { Leaf Spot } \\
\text { Disease }\end{array}$ & 4 & $\begin{array}{c}\text { Bercak-Bercak Coklat Seperti } \\
\text { Terbakar }\end{array}$ & $\begin{array}{l}\text { Medium- } \\
\text { Tinggi }\end{array}$ & Daun \\
\hline & Ulat & 2 & $\begin{array}{c}\text { Daun Menggulung dan } \\
\text { Berlubang }\end{array}$ & Rendah & Daun \\
\hline & Kutu & 1 & Bekas Telur Menggerombol & $\begin{array}{l}\text { Rendah- } \\
\text { Medium }\end{array}$ & Batang \\
\hline & Kanker & 1 & Tonjolan Warna Coklat & $\begin{array}{l}\text { Rendah- } \\
\text { Medium }\end{array}$ & Batang \\
\hline & $\begin{array}{l}\text { Liana (Tanaman } \\
\text { Pengganggu) }\end{array}$ & 1 & $\begin{array}{c}\text { Cabang Terlilit Derris sp. Hingga } \\
\text { Patah }\end{array}$ & $\begin{array}{l}\text { Medium- } \\
\text { Tinggi }\end{array}$ & Batang \\
\hline & - & 1 & Tumbang & Kritis & $\begin{array}{l}\text { Akar, } \\
\text { Batang }\end{array}$ \\
\hline \multirow[t]{4}{*}{$\begin{array}{l}\text { II A } \\
(12)\end{array}$} & Semut Hitam & 2 & $\begin{array}{c}\text { Sarang Semut Pada Akar dan } \\
\text { Batang }\end{array}$ & Medium & $\begin{array}{l}\text { Akar, } \\
\text { Batang }\end{array}$ \\
\hline & Penggerek Daun & 1 & Guratan Putih & Medium & Daun \\
\hline & Semut Hitam & 2 & $\begin{array}{c}\text { Sarang Semut pada Akar dan } \\
\text { Batang }\end{array}$ & $\begin{array}{l}\text { Rendah- } \\
\text { Medium }\end{array}$ & $\begin{array}{l}\text { Akar, } \\
\text { Batang }\end{array}$ \\
\hline & $\begin{array}{l}\text { Kurang } \\
\text { Magnesium }\end{array}$ & 1 & $\begin{array}{l}\text { Daun Kuning dan Pucat. } \\
\text { Beberapa Tulang Daunnya Hijau }\end{array}$ & Medium & Daun \\
\hline
\end{tabular}


Jurnal Tanah dan Sumberdaya Lahan Vol 7 No 2 : 305-314, 2020

e-ISSN:2549-9793, doi: 10.21776/ub.jts1.2020.007.2.15

\begin{tabular}{|c|c|c|c|c|c|}
\hline Vak & $\begin{array}{c}\text { HPT dan jenis } \\
\text { pengganggu } \\
\text { lainnya }\end{array}$ & $\begin{array}{c}\text { Jumlah } \\
\text { Tumbuhan } \\
\text { Koleksi } \\
\text { yang } \\
\text { Terserang }\end{array}$ & Gejala & $\begin{array}{l}\text { Tingkat } \\
\text { Serangan }\end{array}$ & $\begin{array}{c}\text { Terserang } \\
\text { Bagian }\end{array}$ \\
\hline & Wereng Lilin & 1 & $\begin{array}{l}\text { Koloni Wereng Lilin pada } \\
\text { Ranting dan Daun }\end{array}$ & Medium & Daun \\
\hline & - & 2 & Cabang Patah (Tersangkut) & Medium & Batang \\
\hline & Kurang Air & 1 & $\begin{array}{c}\text { Daun Berwarna Coklat } \\
\text { Kemerahan }\end{array}$ & Rendah & Daun \\
\hline & $\begin{array}{l}\text { Leaf Spot } \\
\text { Disease }\end{array}$ & 2 & $\begin{array}{c}\text { Daun Kering, Bercak-Bercak } \\
\text { Karat }\end{array}$ & Medium & Daun \\
\hline \multirow{9}{*}{$\begin{array}{l}\text { II B } \\
(25)\end{array}$} & Wilt & 1 & Daun Layu & Rendah & Daun \\
\hline & $\begin{array}{l}\text { Penyakit Jamur } \\
\text { Akar Merah }\end{array}$ & 1 & Terdapat Jamur pada Batang & Medium & Batang \\
\hline & Semut Hitam & 11 & $\begin{array}{l}\text { Sarang Semut Pada Akar dan } \\
\text { Batang }\end{array}$ & $\begin{array}{l}\text { Rendah- } \\
\text { Tinggi }\end{array}$ & $\begin{array}{l}\text { Akar, } \\
\text { Batang }\end{array}$ \\
\hline & $\begin{array}{l}\text { Benalu } \\
\text { (Tanaman }\end{array}$ & 1 & $\begin{array}{c}\text { Tumbuh Tanaman Lain pada } \\
\text { Batang }\end{array}$ & $\begin{array}{l}\text { Rendah- } \\
\text { Medium }\end{array}$ & Batang \\
\hline & Pengganggu) & & & & \\
\hline & Kanker & 1 & Batang Benjol & Medium & Batang \\
\hline & Penggerek Daun & 2 & $\begin{array}{c}\text { Guratan Putih Transparan, } \\
\text { Berlubang }\end{array}$ & Tinggi & Daun \\
\hline & Wereng Lilin & 7 & Bercak-Bercak Tepung Putih & $\begin{array}{l}\text { Rendah- } \\
\text { Medium }\end{array}$ & Daun \\
\hline & $\begin{array}{l}\text { Leaf Spot } \\
\text { Disease }\end{array}$ & 1 & Bercak-Bercak Kering & $\begin{array}{l}\text { Medium- } \\
\text { Tinggi }\end{array}$ & Daun \\
\hline \multirow[t]{5}{*}{$\begin{array}{c}\text { II C } \\
(7)\end{array}$} & $\begin{array}{l}\text { Leaf Spot } \\
\text { Disease }\end{array}$ & 2 & $\begin{array}{l}\text { Bercak Hitam. Bercak Putih } \\
\text { Mirip Hifa pada Belakang Daun }\end{array}$ & Medium & Daun \\
\hline & - & 1 & $\begin{array}{c}\text { Tanpa Daun, Cabang Tertutup } \\
\text { Liana }\end{array}$ & Kritis & $\begin{array}{l}\text { Daun, } \\
\text { Batang }\end{array}$ \\
\hline & Wereng Lilin & 1 & $\begin{array}{l}\text { Wereng Lilin pada Daun dan } \\
\text { Pangkal Daun. }\end{array}$ & Tinggi & Daun \\
\hline & Kutu & 1 & Kutu Cokelat pada Bunga & Tinggi & Bunga \\
\hline & Semut Hitam & 2 & $\begin{array}{l}\text { Batang Berlubang. Gundukan } \\
\text { Tanah pada Akar }\end{array}$ & Medium & $\begin{array}{l}\text { Akar, } \\
\text { Batang }\end{array}$ \\
\hline \multirow[t]{3}{*}{$\begin{array}{c}\text { II D } \\
(6)\end{array}$} & Semut Hitam & 4 & $\begin{array}{l}\text { Sarang Semut pada Akar dan } \\
\text { Batang }\end{array}$ & $\begin{array}{l}\text { Rendah- } \\
\text { Medium }\end{array}$ & $\begin{array}{l}\text { Akar, } \\
\text { Batang }\end{array}$ \\
\hline & $\begin{array}{l}\text { Leaf Spot } \\
\text { Disease }\end{array}$ & 1 & Hifa Hitam pada Daun & Tinggi & Daun \\
\hline & Wereng Lilin & 1 & Wereng Lilin pada Daun & Medium & Daun \\
\hline \multirow[t]{5}{*}{$\begin{array}{c}\text { II E } \\
(6)\end{array}$} & $\begin{array}{l}\text { Liana (Tanaman } \\
\text { Pengganggu) }\end{array}$ & 2 & Liana Tumbuh Banyak & Tinggi & Batang \\
\hline & Semut Hitam & 1 & Keropos, Cabang Rawan Patah & Tinggi & Batang \\
\hline & - & 1 & Tanpa Daun. Kering & Kritis & Daun \\
\hline & - & 1 & Tegakan Mulai Miring & Tinggi & Batang \\
\hline & Wereng Lilin & 1 & Bercak-Bercak Tepung Putih & Medium & Daun \\
\hline \multirow[t]{5}{*}{$\begin{array}{l}\text { III A } \\
1(26)\end{array}$} & Semut Hitam & 4 & $\begin{array}{c}\text { Batang Atas Lapuk. Lubang } \\
\text { Besar pada Batang }\end{array}$ & Medium & Batang \\
\hline & Kurang Air & 5 & Daun Kering, Menguning & Medium & Daun \\
\hline & $\begin{array}{l}\text { Leaf Spot } \\
\text { Disease }\end{array}$ & 7 & $\begin{array}{c}\text { Daun Kuning-Kering. Pinggir } \\
\text { Daun Mengering }\end{array}$ & Medium & Daun \\
\hline & Kurang Zat Besi & 1 & Daun Menguning-Pucat & Medium & Daun \\
\hline & Belalang & 3 & Daun Berlubang & Medium & Daun \\
\hline
\end{tabular}


Jurnal Tanah dan Sumberdaya Lahan Vol 7 No 2 : 305-314, 2020

e-ISSN:2549-9793, doi: 10.21776/ub.jts1.2020.007.2.15

\begin{tabular}{|c|c|c|c|c|c|}
\hline Vak & $\begin{array}{l}\text { HPT dan jenis } \\
\text { pengganggu } \\
\text { lainnya }\end{array}$ & $\begin{array}{c}\text { Jumlah } \\
\text { Tumbuhan } \\
\text { Koleksi } \\
\text { yang } \\
\text { Terserang }\end{array}$ & Gejala & $\begin{array}{l}\text { Tingkat } \\
\text { Serangan }\end{array}$ & $\begin{array}{c}\text { Terserang } \\
\text { Bagian }\end{array}$ \\
\hline & $\begin{array}{l}\text { Liana (Tanaman } \\
\text { Pengganggu) }\end{array}$ & 4 & Rumpun Tertutup Liana & $\begin{array}{l}\text { Medium- } \\
\text { Tinggi }\end{array}$ & Rumpun \\
\hline & $\begin{array}{l}\text { Gulma } \\
\text { (Tanaman } \\
\text { Pengganggu) }\end{array}$ & 1 & $\begin{array}{l}\text { Daun Kuning-Kering. } \\
\text { Ditumbuhi Gulma }\end{array}$ & Tinggi & $\begin{array}{l}\text { Ditumbuhi, } \\
\text { Daun }\end{array}$ \\
\hline & - & 1 & Batang dan Daun Kering & Kritis & $\begin{array}{l}\text { Daun, } \\
\text { Batang }\end{array}$ \\
\hline \multirow[t]{4}{*}{$\begin{array}{l}\text { III B } \\
(5)\end{array}$} & $\begin{array}{l}\text { Leaf Spot } \\
\text { Disease }\end{array}$ & 1 & Bercak Karat pada Daun & Tinggi & Daun \\
\hline & - & 2 & Tegakan Mulai Miring & $\begin{array}{l}\text { Medium- } \\
\text { Tinggi }\end{array}$ & Batang \\
\hline & - & 1 & $\begin{array}{c}\text { Ambruk ke Koleksi Akuatik, } \\
\text { Hidup }\end{array}$ & Tinggi & Batang \\
\hline & Semut Hitam & 1 & Batang Berlubang & Kritis & Batang \\
\hline \multirow[t]{4}{*}{$\begin{array}{c}\text { III C } \\
(6)\end{array}$} & $\begin{array}{l}\text { Leaf Spot } \\
\text { Disease }\end{array}$ & 1 & $\begin{array}{c}\text { Spora Jamur Warna Hitam pada } \\
\text { Belakang Daun }\end{array}$ & Medium & Daun \\
\hline & Semut Hitam & 3 & $\begin{array}{c}\text { Batang Berlubang, terdapat } \\
\text { Sarang Semut }\end{array}$ & Medium & Batang \\
\hline & - & 1 & Tidak Berdaun. Batang Ambruk & Kritis & $\begin{array}{l}\text { Daun, } \\
\text { Batang }\end{array}$ \\
\hline & - & 1 & Cabang Hampir Patah & Tinggi & Batang \\
\hline \multirow{6}{*}{$\begin{array}{c}\text { III D } \\
(9)\end{array}$} & Semut Hitam & 1 & Tegakan Mulai Miring & Medium & Batang \\
\hline & $\begin{array}{c}\text { Benalu } \\
\text { (Tanaman } \\
\text { Pengganggu) }\end{array}$ & 3 & Ditumbuhi Benalu & Tinggi & Benalu \\
\hline & Semut Hitam & 2 & Batang Lapuk. Tanpa Daun & Kritis & $\begin{array}{l}\text { Daun, } \\
\text { Batang }\end{array}$ \\
\hline & Kumbang Badak & 1 & Pelepah Berlubang & Medium & Pelepah \\
\hline & $\begin{array}{l}\text { Leaf Spot } \\
\text { Disease }\end{array}$ & 1 & Nekrosis & Medium & Daun \\
\hline & Semut Hitam & 1 & Batang Berlubang & Rendah & Batang \\
\hline $\begin{array}{l}\text { III E } \\
(1)\end{array}$ & - & 1 & Mulai Ambruk & Tinggi & Batang \\
\hline \multirow[t]{5}{*}{$\begin{array}{l}\text { III F } \\
(14)\end{array}$} & $\begin{array}{c}\text { Benalu } \\
\text { (Tanaman } \\
\text { Pengganggu }\end{array}$ & 3 & $\begin{array}{l}\text { Ditumbuhi Benalu, Menembus } \\
\text { Palem }\end{array}$ & Kritis & Benalu \\
\hline & $\begin{array}{l}\text { Leaf Spot } \\
\text { Disease }\end{array}$ & 6 & Nekrosis & Medium & Daun \\
\hline & - & 3 & Tanpa Daun. Batang Kering & $\begin{array}{l}\text { Tanpa Daun. } \\
\text { Batang } \\
\text { Kering }\end{array}$ & $\begin{array}{l}\text { Daun, } \\
\text { Batang }\end{array}$ \\
\hline & - & 1 & $\begin{array}{c}\text { Menyebabkan Kerusakan secara } \\
\text { Mekanik Akar Terkoyak }\end{array}$ & $\begin{array}{l}\text { Rendah- } \\
\text { Medium }\end{array}$ & Akar \\
\hline & Belalang & 1 & Daun Bekas Digerogoti & Medium & Daun \\
\hline \multirow[t]{2}{*}{$\begin{array}{c}\mathrm{III} G \\
(6)\end{array}$} & $\begin{array}{l}\text { Leaf Spot } \\
\text { Disease }\end{array}$ & 5 & $\begin{array}{c}\text { Daun Kering dari Pinggir Ke } \\
\text { Tengah Helai. Berlubang, } \\
\text { Terkoyak }\end{array}$ & $\begin{array}{l}\text { Rendah- } \\
\text { Kritis }\end{array}$ & Daun \\
\hline & $\begin{array}{l}\text { Penyakit Jamur } \\
\text { Akar Merah }\end{array}$ & 1 & Tegakan Mulai Miring & Medium & Batang \\
\hline
\end{tabular}


Jurnal Tanah dan Sumberdaya Lahan Vol 7 No 2 : 305-314, 2020

e-ISSN:2549-9793, doi: 10.21776/ub.jts1.2020.007.2.15

\begin{tabular}{|c|c|c|c|c|c|}
\hline Vak & $\begin{array}{l}\text { HPT dan jenis } \\
\text { pengganggu } \\
\text { lainnya }\end{array}$ & $\begin{array}{c}\text { Jumlah } \\
\text { Tumbuhan } \\
\text { Koleksi } \\
\text { yang } \\
\text { Terserang }\end{array}$ & Gejala & $\begin{array}{l}\text { Tingkat } \\
\text { Serangan }\end{array}$ & $\begin{array}{c}\text { Terserang } \\
\text { Bagian }\end{array}$ \\
\hline \multirow{2}{*}{$\begin{array}{c}\text { III H } \\
1(4)\end{array}$} & Semut Hitam & 1 & Sarang Semut pada Pangkal Daun & Medium & Daun \\
\hline & $\begin{array}{l}\text { Leaf Spot } \\
\text { Disease }\end{array}$ & 3 & $\begin{array}{c}\text { Daun Kering, Bercak-Bercak } \\
\text { Cokelat Kering }\end{array}$ & Tinggi & Daun \\
\hline \multirow[t]{3}{*}{$\begin{array}{l}\text { IV A } \\
1(3)\end{array}$} & $\begin{array}{l}\text { Leaf Spot } \\
\text { Disease }\end{array}$ & 1 & Bercak Karat pada Daun & Medium & Daun \\
\hline & $\begin{array}{l}\text { Penyakit Jamur } \\
\text { Akar Merah }\end{array}$ & 1 & Terdapat Jamur pada Batang & Kritis & Batang \\
\hline & - & 1 & Tersisa Pangkal Batang & Kritis & Batang \\
\hline \multirow{8}{*}{$\begin{array}{c}\text { IV B } \\
(17)\end{array}$} & Kanker & 1 & Benjolan pada Batang & Medium & Batang \\
\hline & Semut Hitam & 4 & Sarang Semut pada Akar & Medium & Akar \\
\hline & - & 2 & Tegakan Miring & Medium & Batang \\
\hline & - & 1 & Tanpa Daun. Pangkal Batang & Kritis & $\begin{array}{l}\text { Daun, } \\
\text { Batang }\end{array}$ \\
\hline & $\begin{array}{l}\text { Penyakit Embun } \\
\text { Jelaga }\end{array}$ & 1 & Bercak Hitam pada Daun & Rendah & Daun \\
\hline & $\begin{array}{c}\text { Kurang } \\
\text { Magnesium }\end{array}$ & 4 & $\begin{array}{l}\text { Hampir Tanpa Daun. Daun } \\
\text { Kuning, Tulang Daun Hijau }\end{array}$ & Tinggi & Daun \\
\hline & Wereng Lilin & 3 & $\begin{array}{l}\text { Daun Menguning, Pucuk Kering. } \\
\text { Tepung Putih pada Daun }\end{array}$ & Tinggi & Daun \\
\hline & $\begin{array}{l}\text { Leaf Spot } \\
\text { Disease }\end{array}$ & 1 & $\begin{array}{c}\text { Daun Kering, Hijau Hanya } \\
\text { Pucuk }\end{array}$ & Tinggi & Daun \\
\hline \multirow[t]{6}{*}{$\begin{array}{l}\mathrm{IV} \mathrm{C} \\
(12)\end{array}$} & Semut Hitam & 2 & $\begin{array}{c}\text { Batang Keropos. Tunas Daun } \\
\text { Mengering }\end{array}$ & $\begin{array}{l}\text { Medium- } \\
\text { Kritis }\end{array}$ & $\begin{array}{l}\text { Daun, } \\
\text { Batang }\end{array}$ \\
\hline & - & 3 & Tegakan Miring & $\begin{array}{l}\text { Medium- } \\
\text { Kritis }\end{array}$ & Batang \\
\hline & Semut Merah & 1 & $\begin{array}{c}\text { Daun Melekat Menjadi Sarang } \\
\text { Semut }\end{array}$ & Medium & Daun \\
\hline & Kanker & 1 & Kanker & Rendah & Batang \\
\hline & $\begin{array}{l}\text { Semut Hitam } \\
\text { Dan Jamur }\end{array}$ & 3 & $\begin{array}{c}\text { Batang Keropos. Tunas Daun } \\
\text { Mengering }\end{array}$ & Kritis & $\begin{array}{l}\text { Daun, } \\
\text { Batang }\end{array}$ \\
\hline & $\begin{array}{l}\text { Leaf Spot } \\
\text { Disease }\end{array}$ & 2 & $\begin{array}{l}\text { Daun Menguning di Ujung } \\
\text { Cabang }\end{array}$ & Rendah & Daun \\
\hline \multirow[t]{2}{*}{$\begin{array}{c}\text { IV D } \\
(2)\end{array}$} & Semut Hitam & 1 & $\begin{array}{c}\text { Kulit Batang Mengelupas, Batang } \\
\text { Berlubang Kecil-Kecil }\end{array}$ & Tinggi & Batang \\
\hline & Semut Hitam & 1 & $\begin{array}{c}\text { Tanpa Daun. Sarang Semut pada } \\
\text { Batang, Batang Kering }\end{array}$ & Kritis & $\begin{array}{l}\text { Daun, } \\
\text { Batang }\end{array}$ \\
\hline \multirow[t]{2}{*}{$\begin{array}{l}\text { IV D } \\
4(6)\end{array}$} & - & 4 & $\begin{array}{l}\text { Ambruk, Masih Hidup dan Ada } \\
\text { yang Layu }\end{array}$ & Tinggi & $\begin{array}{l}\text { Akar, } \\
\text { Batang }\end{array}$ \\
\hline & Kepik Hitam & 2 & $\begin{array}{l}\text { Koloni Kepik Hitam pada Batang } \\
\text { dan Daun }\end{array}$ & Medium & $\begin{array}{l}\text { Daun, } \\
\text { Batang }\end{array}$ \\
\hline \multirow[t]{4}{*}{$\begin{array}{l}\text { IV D } \\
6(18)\end{array}$} & Semut Hitam & 8 & $\begin{array}{c}\text { Daun Kering dan Gugur. Batang } \\
\text { Keropos }\end{array}$ & Kritis & $\begin{array}{l}\text { Daun, } \\
\text { Batang }\end{array}$ \\
\hline & Kanker & 1 & Kanker pada Akar & Medium & Akar \\
\hline & - & 4 & Tersisa Tunggak & Kritis & Akar \\
\hline & $\begin{array}{c}\text { Kurang } \\
\text { Magnesium }\end{array}$ & 5 & Daun Sedikit dan Menguning & Medium & Daun \\
\hline
\end{tabular}


Jurnal Tanah dan Sumberdaya Lahan Vol 7 No 2 : 305-314, 2020

e-ISSN:2549-9793, doi: 10.21776/ub.jts1.2020.007.2.15

\begin{tabular}{cccccc}
\hline Vak & $\begin{array}{c}\text { HPT dan jenis } \\
\text { pengganggu } \\
\text { lainnya }\end{array}$ & $\begin{array}{c}\text { Jumlah } \\
\text { Tumbuhan } \\
\text { Koleksi } \\
\text { yang } \\
\text { Terserang }\end{array}$ & Gejala & $\begin{array}{c}\text { Tingkat } \\
\text { Serangan }\end{array}$ & $\begin{array}{c}\text { Terserang } \\
\text { Bagian }\end{array}$ \\
\hline $\begin{array}{c}\text { V C } \\
(5)\end{array}$ & Kanker & 1 & Terdapat Kanker pada Akar & Rendah & Akar \\
& Semut Hitam & 4 & Sarang Semut pada Akar dan & Medium & Akar, \\
Batang
\end{tabular}

Hama yang menyerang tumbuhan koleksi antara lain wereng lilin, semut hitam, semut merah, kepik, ulat, kutu, penggerek daun, belalang, dan kumbang badak. Penyakit yang menyerang tumbuhan koleksi antara lain leaf spot disease, wilt, kurang kalsium, kurang unsur hara terutama air, kanker, kurang magnesium, jamur akar merah, kurang zat besi, dan embun jelaga. Hama dan penyakit tanaman yang terdaftar tersebut didominasi oleh leaf spot disease, semut merah, semut hitam, serta wereng lilin.

\section{Leaf spot disease}

Terkait penyakit Leaf Spot Desease (LSD) atau sering disebut penyakit bercak daun, Saleh (2010) menyatakan bahwa pada umumnya gejala dan tanda penyakit bercak daun adalah terbentuknya daerah yang mati pada daun (nekrosis) (Gambar 1). Luas daerah nekrosis bervariasi mulai dari yang kecil sampai yang besar dengan bentuk dari yang tidak beraturan sampai yang beraturan. Begitu pula dengan warna bercak atau daerah nekrosis tadi beragam mulai dari kuning, coklat hingga hitam. Terkait karakteristiknya, Boyce (1961) juga menyatakan bahwa karakteristik dari penyakit bercak daun adalah terbentuknya daerah-daerah mati pada daun, deaerah tersebut bervariasi dalam ukuran dan bentuk. Jaringan daun yang mengalami nekrosis biasanya tidak menyeluruh kecuali apabila jumlah bercak saling bersatu dan membentuk bercak yang luas.

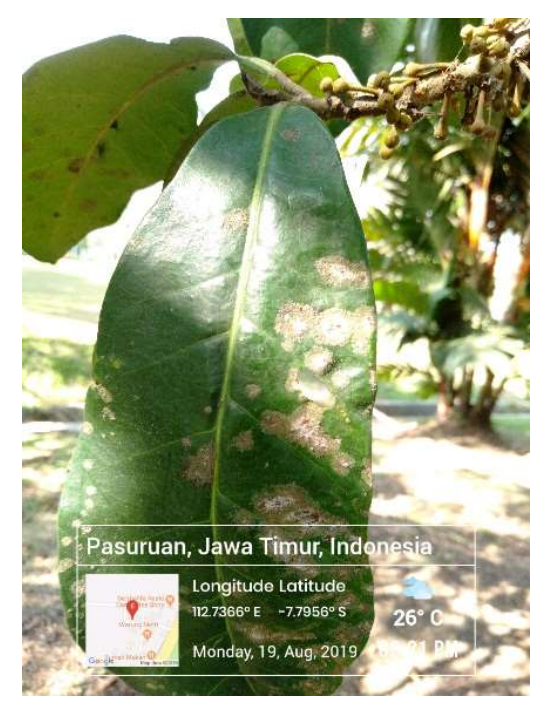

Gambar 1. LSD pada suku Sapotaceae pada Vak III.

\section{Semut merah / semut rang-rang}

Semut rang-rang (Oecopbylla smaragdina) dapat diklasifikasikan : 


$\begin{array}{lll}\text { Kingdom } & : & \text { Animalia } \\ \text { Phylum } & : & \text { Arthopoda } \\ \text { Kelas } & : & \text { Insecta } \\ \text { Ordo } & : & \text { Hymonoptera } \\ \text { Famili } & : & \text { Formisidae } \\ \text { Genus } & : & \text { Oecophylla } \\ \text { Spesies } & : & \text { Oecophylla smaragdina }\end{array}$

Gangguan dan gejala yang ditimbulkan oleh semut merah/rang-rang hanya sedikit yaitu beberapa daun yang ada di pohon saling melekat membentuk sarang semut merah sehingga membuat rusak daun-daun tersebut (Gambar 2). Namun hal ini tidak terlalu menjadi dominasi pada kerusakan pohon secara keseluruhan. Hal itu karena semut merah lebih dikenal sebagai predator hama atau musuh alami hama.

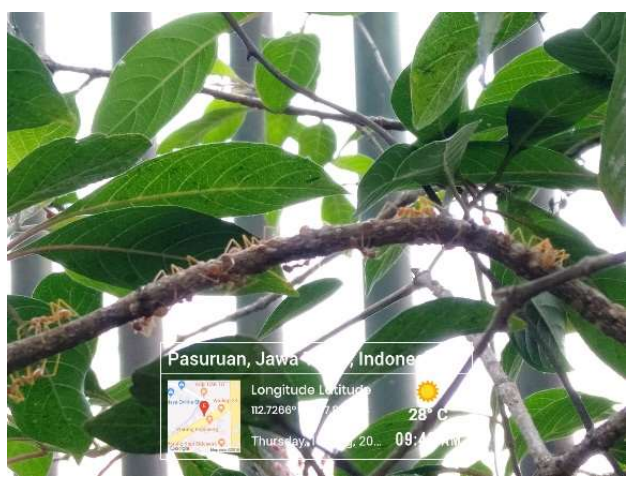

Gambar 2. Semut rang-rang pada salah satu tumbuhan suku Sterculiaceae pada Vak I.

Huang dan Yang (1987) menyatakan bahwa semut rang-rang sudah dikenal oleh bangsa China pada tahun 304 Masehi untuk mengendalikan hama kutu kutuan pada tanaman jeruk. Perilaku agresif semut rangrang dalam mempertahankan daerah kekuasaannya barangkali menjadi salah satu pertimbangan bagi para petani untuk menggunakannya sebagai "penjaga" tanaman terhadap gangguan hama. Way dan Khoo (1992) menyebutkan bahwa semut rangrang menjadi musuh alami pada sekitar 16 spesies hama yang menyerang spesies tanaman, yaitu kakao, kelapa, kelapa sawit, mangga, eukaliptus, dan jeruk. Bersama dengan kerabatnya, yaitu Oecophylla longinoda (Afrika dan Australia), semut rangrang Oecophylla smaragdina melindungi tanaman-tanaman tersebut dari serangan hama. Penelitian lain juga membuktikan bahwa semut rangrang menjadi musuh alami hama pada tanaman lada hitam dan mahoni. Misalnya, Offenberg et al. (2006) menyebutkan bahwa semut rangrang mampu melindungi tanaman mangrove dari serangan kepiting Episesarma versicolor. Salah satu jenis semut yang banyak digunakan dalam mengendalikan hama pertanian antara lain jenis semut rang-rang (Oecophylla smaragdina). Oecophyilla smaragdina adalah semut yang dominan di hutan terbuka dari India, Australia, Cina dan Asia Tenggara. Dari beberapa penelitian yang telah ada, banyak petani yang menggunakan semut rangrang sebagai pengendalinya. Lim (2007), menggunakan Oecophylla sebagai musuh alami dalam pengendalian hama di pohon mahogani..

\section{Semut hitam}

Semut hitam (Lasius fuligunosus) dapat diklasifikasikan :

$\begin{array}{lll}\text { Kingdom } & : & \text { Animalia } \\ \text { Filum } & : & \text { Artropoda } \\ \text { Kelas } & : & \text { Insekta } \\ \text { Ordo } & : & \text { Hymenoptera } \\ \text { Divisi } & : & \text { Holometabola } \\ \text { Class } & : & \text { Insecta } \\ \text { Famili } & : & \text { Formicidae } \\ \text { Genus } & : & \text { Lacius } \\ \text { Species } & : & \text { Lasius fuliginosus }\end{array}$

Semut ini membuat sarang berupa gundukan tanah memanjang di bagian pangkal batang pohon, biasanya juga bersarang di bawah tangkai daun, dan mereka hidup berkelompok (Gambar 3). Semut hitam ini sering memakan serangga lain misalnya ulat, semut hitam bisa juga mengurangi serangan hama pada tanaman yang di tempatinya, tetapi semut hitam ini bisa membuat kulit ranting menjadi terkelupas sehingga bakteri dapat dengan mudah menyerang, kerugian lain yang di timbulkan adalah kesulitan pada waktu perawatan dan penebangan, karena bisa menggangu aktifitas. Kehadiran dari semut ini menyebabkan munculnya penyakit sekunder misalnya jamur yang dapat menyebabkan penyakit. Semut ini juga dapat merusak akar dan tunas muda, sehingga banyak kerusakan yang ditimbulkan semut ini (Sari, 2013). 


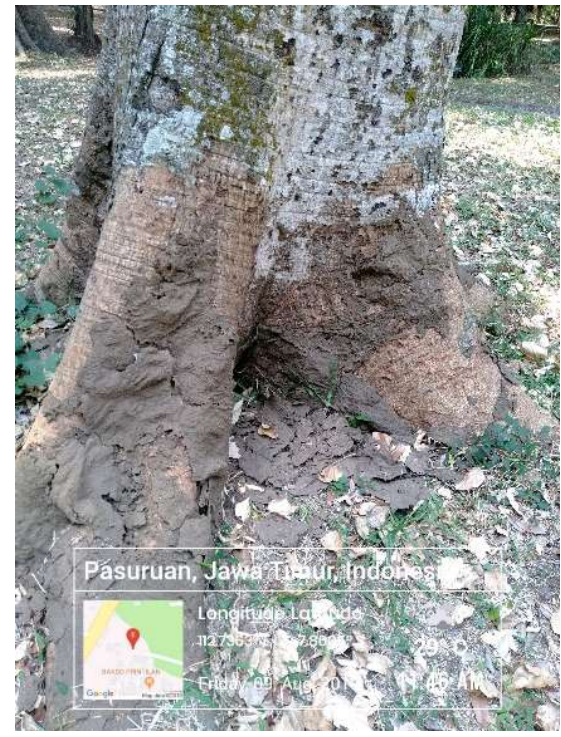

Gambar 3. Sarang semut hitam pada salah satu tumbuhan suku Mimosaceae pada Vak I.

\section{Wereng lilin}

Hama wereng lilin ini biasa menyerang setiap saat terutama saat musim penghujan. Bagian tanaman yang diserang adalah pucuk (jaringan meristematis) (Gambar 4).

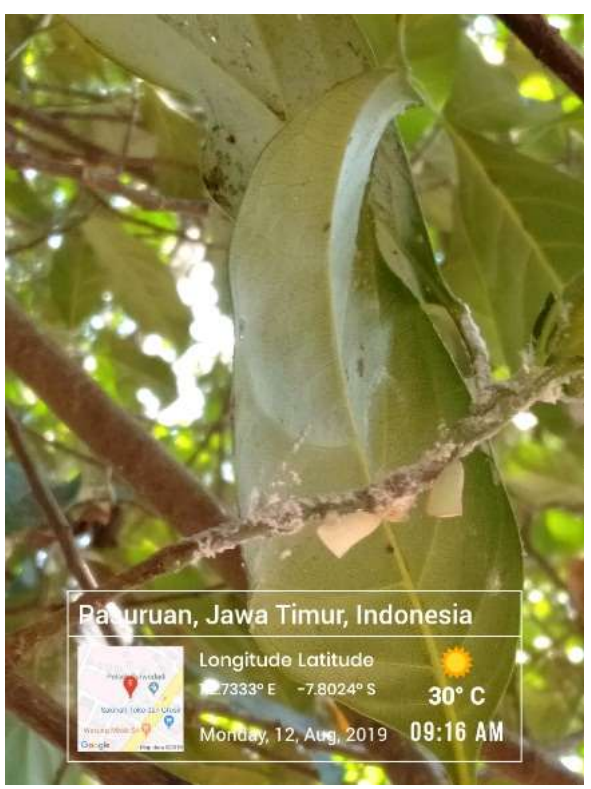

Gambar 4. Wereng lilin pada salah satu tumbuhan suku Moraceae pada Vak IV.
Wereng lilin dapat menyerang baik pada daun, cabang, dan batang tanaman. Jika hama ini menyerang pada daun, lebih banyak ditemukan pada permukaan daun bagian bawah, terutama pada fase nimfa, dan terlihat nimfa tertutup dengan lapisan lilin tebal sehingga bagian yang terserang tersebut seperti tertutup kapas. Wereng lilin dapat menusuk dan menghisap cairan tanaman. Sehingga bagian tanaman yang terserang akan menjadi rusak dan akan menghambat pertumbuhan dari tanaman tersebut. Langkah awal pengendalian berupa pemisahan bibit yang sakit dengan yang sehat karena bisa menular. Apabila batang bibit tersebut sudah terserang, batang dapat dipotong 0,5-1 cm di atas permukaan media; pucuk yang sakit dibuang/dimusnahkan. Jika serangan sudah parah dan dalam skala yang luas maka dapat dilakukan penyemprotan dengan menggunakan akarisida.

\section{Kesimpulan}

Hama dan penyakit di 24 sub vak KRP tersebut, ditemukan sembilan jenis hama dan sembilan jenis penyakit serta ada beberapa tanaman pengganggu (parasit) lainnya yang merusak tumbuhan koleksi seperti liana, gulma, dan benalu. Hama yang menyerang tumbuhan koleksi antara lain wereng lilin, semut hitam, semut merah, kepik, ulat, kutu, penggerek daun, belalang, dan kumbang badak. Penyakit yang menyerang tumbuhan koleksi antara lain leaf spot disease, wilt, kurang kalsium, kurang unsur hara terutama air, kanker, kurang magnesium, jamur akar merah, kurang zat besi, dan embun jelaga. Hama dan Penyakit didominasi oleh Leaf Spot Disease, Semut Hitam, Semut Merah, serta Wereng Lilin. Suku tanaman yang terserang di bebarapa sub vak tersebut atara lain dari suku Sapotaceae, Sterculiaceae, Mimosaceae, Moraceae, dll.

\section{Ucapan Terima Kasih}

Penulis mengucapkan terima kasih kepada (1) Kepala Pusat Penelitian Konservasi Tumbuhan dan Kebun Raya dan Kepala BKT Kebun Raya Purwodadi-LIPI atas arahan, bimbingan, dukungan dan motivasinya dalam peningkatan penelitian, (2) Pihak Institut Pertanian Malang atas kerjasama dan dukungannya terhadap peningkatan tugas dan fungsi BKT. Kebun 
Jurnal Tanah dan Sumberdaya Lahan Vol 7 No 2 : 305-314, 2020

e-ISSN:2549-9793, doi: 10.21776/ub.jts1.2020.007.2.15

Raya Purwodadi, dan (3) Para pegawai di Kebun Raya yang selalu siap dalam membantu pengamatan penelitian ini.

\section{Daftar Pustaka}

Boyce, J.S. 1961. Forest Pathology. Third Edition. McGraw Hill Book Company, Inc. New York.

Damaiyani, J. dan Lestari, D. 2011. Inventarisasi hama dan penyakit pada koleksi paku-pakuan Kebun Raya Purwodadi. Berkala Penelitian Hayati. Edisi Khusus 7A: 173-177.

Huang, H.T. and Yang P. 1987. The ancient cultured citrus ant. Journal of Bioscience 37: 665-671.

Lim, G.T. 2007. Enhancing The Weaver Ant, Oecophylla smaragdina for Biological Control of a Shoot Borer, Hypsipilla robusta in Malaysia Mahagony Plantation. Dissertation the Virginia Polythecnic Institute and State University. Virginia.

Nasution, A.S. 2008. Pengenalan Patologi/Penyakit Tumbuhan. http:/ /sanoesi. wordpress.com/2008/12/17/pengenalanpatologipenyakit-tumbuhan/ (Diakses September 2019).
Offenberg, J., Havanon, S, Aksornkoae, S. and Macintosh, D.J. 2006. Observations on the ecology of Weaver Ants (Oecophylla smaragdina Fabricius) in a Thai mangrove ecosystem and their effect on herbivory of Rhizophora mucronata Lam. Biotropica 36(3): 344-351, doi: 10.1111/j.1744-7429.2004.tb00326.x

Pracaya. 1992. Hama dan Penyalit Tanaman. Penebar Swadaya. Jakarta.

Pranata. 1982. Hama dan Penyakit Tanaman. Penebar Swadaya, Jakarta.

Saleh, N. 2010. Optimalisai pengendalian terpadu penyakit bercak daun dan karat pada kacang tanah. Pengembangan Inovasi Pertanian 3(4):289-305.

Sari, D.K. 2013. Identifikasi Serangga Penyebab Hama pada Beberapa Genus Anggrek Koleksi Kebun Raya Purwodadi-Lipi. Jurusan Biologi Fakultas Matematika dan Ilmu Pengetahuan Alam Universitas Brawijaya. Malang.

Triharso. 1996. Dasar-Dasar Perlindungan Tanaman. Gadjah Mada University Press, Yogyakarta.

Way, M.J. and Khoo, K.C. 1992. Role of ants in pest management. Annual Review of Entomology 37: 479-503 